\title{
Urethral Cancer pN2 TNM Finding v8
}

National Cancer Institute

\section{Source}

National Cancer Institute. Urethral CancerpN2 TNM Finding v8. NCI Thesaurus. Code C140456.

Urethral cancer with multiple regional lymph node metastasis in the inguinal region or true pelvis [perivesical, obturator, internal (hypogastric) and external iliac], or presacral lymph node. (from AJCC 8th Ed.) 